Article

\title{
Analysis of the Effects of Water Management Strategies and Climate Change on the Environmental and Agricultural Sustainability of Urmia Lake Basin, Iran
}

\author{
Jamal Ahmadaali ${ }^{1, *}$, Gholam-Abbas Barani ${ }^{2}$, Kourosh Qaderi ${ }^{1}$ and Behzad Hessari ${ }^{3}$ \\ 1 Department of Water Engineering, Faculty of Agriculture, Shahid Bahonar University of Kerman, \\ Kerman 76169-14111, Iran; kouroshqaderi@uk.ac.ir \\ 2 Department of Civil Engineering, Faculty of Engineering, Shahid Bahonar University of Kerman, \\ Kerman 76169-14111, Iran; gab@uk.ac.ir \\ 3 Water Engineering Department, Urmia Lake Research Institute, Urmia University, Urmia 57179-44514, Iran; \\ b.hessari@urmia.ac.ir \\ * Correspondence: jamalahmadaali@gmail.com; Tel.: +98-914-4403437
}

Received: 17 December 2017; Accepted: 31 January 2018; Published: 7 February 2018

\begin{abstract}
In arid and semi-arid areas, unsustainable development of irrigated agriculture has reduced the water level of large lakes such as Aral, Urmia, Hamoon, and Bakhtegan. Urmia Lake, as a hyper saline and very shallow lake, located in the northwest of Iran, has water level reductions of about $40 \mathrm{~cm}$ each year over the past two decades. In this research, the indices of environmental and agricultural sustainability are evaluated using performance criteria influenced by climate change and water management strategies for the Zarrinehrud and Siminehrud River basins as the largest sub-basin of Urmia Lake basin. Modeling of hydrologic behavior of these basins is performed using WEAP21 model. The model is analyzed for three future emission scenarios (A2, A1B, and B1), for the period of 2015-2040 and five water management scenarios: (1) keeping the existing situation; (2) crop pattern change; (3) improving the conveyance and distribution efficiency; (4) combining the improvement of conveyance and distribution efficiency with improving the application efficiency using modern technology; and (5) the combination of crop pattern change with the improvement of total irrigation efficiency. The results show that the highest values of indices of environmental sustainability and agricultural sustainability are related to the scenario of combining the crop pattern change with improving the total irrigation efficiency under the B1 emission scenario (B1S4).
\end{abstract}

Keywords: climate change; water management; WEAP21 model; scenario analysis; Urmia Lake; sustainability index

\section{Introduction}

In basins where water consumption is mostly for irrigation, sustainable management of water resources must consider two goals simultaneously: sustainable irrigated agriculture to ensure food security and protection of the environment. It is necessary to establish sustainable interaction between these two goals in the present and future, and at the same time decrease potential conflicts between these two goals with the help of methods such as the application of new methods of irrigation, preventing water loss in the conveyance paths, changing the crop pattern to less water use products, developing greenhouse cultivation, etc. [1]. Increasing water demand often results in unsustainable water consumption and inadequate water remain for environmental protection. To save water for the environment, measures for saving agricultural water have been introduced as an agenda for environmental policy in many arid and semi-arid regions [2]. Törnqvist and Jarsjö [3] investigated the 
hydrological effects of improving irrigation technologies on vast cotton fields in the Aral Sea basin located in Central Asia. The results of their research showed that the implementation of irrigation technologies will lead to water storage and will increase the discharge to the Aral Sea between 1 and $6 \mathrm{~km}^{3}$ per year.

In arid and semi-arid areas, high-consumption agriculture has led to a decrease in the water level of large lakes such as Aral Sea, Urmia Lake, Hamoon Lake, and Bakhtegan Lake [4]. Urmia Lake, the largest lake in Iran and the second most saline lake in the world, has been dying during the last two decades and this has resulted in similar or even greater socio-environmental impacts to the disaster of the Aral Sea [5].

Various studies have been conducted on Urmia Lake regarding the effective factors in reducing the inflow to the lake and they are referred to in the following:

Jalili et al. [6] investigated the effects of climate change and human factors on fluctuations in water level of Urmia Lake. The results showed that the recent decrease in the water level of Urmia Lake is mostly due to human impacts rather than climate change. The results of some research studies [7-10] also confirmed that human factors have a greater impact on drying Urmia Lake than climatic factors. Shadkam et al. [11] examined the effects of climate change and the development of water resources (including constructing dams and increased irrigated agriculture) on the reduction of inflow to the Urmia Lake during the period of 1960 to 2010. The results showed that the annual inflow to Lake Urmia decreased by $48 \%$ during the studied period. About $60 \%$ of this decline was caused by climate change and about $40 \%$ by water resources development. Urmia Lake Basin is located in an area with the following problems: poverty, water stress, soil degradation, natural agro-constraints, and isolation [12].

Generally, hydrological models focus on understanding how water flows within a basin in response to hydrological events, while water resource planning models focus primarily on water allocation management (for example, deciding on supply and demand). The integration of these two components is possible using a single analytical framework. This framework is the Water Evaluation and Planning Model of version 21 (WEAP21), which is a bridge between the basin hydrology and water management by combining the physical hydrological process in the water management framework [13].

In connection with the application of the WEAP model in the analysis of water saving scenarios and the effects of climate change, several studies have been conducted and some of them are referred to in the following.

Joyce et al. [14] reviewed the agricultural water management strategies for adaptation to climate change using the WEAP model. Adaptation strategies include improving irrigation technologies and crop pattern change into more valuable or less water consuming products. Mehta et al. [15], using the WEAP model, examined the supply and demand of irrigation water, due to climate change and land use scenarios in the Cache Creek watershed in California. They tested three scenarios until 2099: (1) crop pattern change based on economic forecasts; (2) change to more varied cultivation patterns and more efficient water use; and (3) combining improvement of irrigation technology and crop pattern change. Their results showed that demand for irrigation water increases by $26 \%$ and $32 \%$, respectively, under the B1 and A2 climatic scenarios at the end of the century. The greatest water saving is achieved in the scenario of combining varied cultivation patterns and more efficient water use, with improvements in irrigation technology, which reduces demand by about $12 \%$ below the mean time. Blanco-Gutiérrez [16] conducted a hydrologic-economic analysis of water management strategies for balancing water for nature (protecting wetlands) and water for food on the Guadiana River Basin in Spain. The results of their study showed that, in periods of long-term droughts (predicted increase in temperature between 1.5 and $3.6^{\circ} \mathrm{C}$ and $10 \%$ to $20 \%$ reduction of precipitation by 2050 ), tensions will be intensified on agriculture, land resources and water resources by decreasing water availability and increasing demand for irrigation water.

Considering the lack of water resources and uncertainty in the climate and future demand, decision-makers need sustainability analysis techniques in water resource management [17]. For the 
first time, Loucks developed an index for quantifying the sustainability of water resource systems using three criteria: reliability, resilience and vulnerability. He defined the sustainability index for assessing the effectiveness of various managerial options from the perspective of stakeholders of water and the environment. Sustainability index estimates system capacity to reduce its vulnerability. If a proposed policy leads to a more stable system, this index indicates that the system has a high capacity to reduce vulnerability in the future. Subsequently, the proposed index was used in numerous studies by researchers [18]. Criteria of reliability, resilience and vulnerability measure various aspects of water resource system performance. These three criteria together provide one of the most comprehensive approaches for analyzing the probability of success or failure of a system, the rate of recovery (or return) of a system from undesirable conditions, and the quantification of expected results in satisfactory modes for long periods [19].

Safavi et al. [20] analyzed the sustainability index of water resources and consumption in Zayandehrud River basin under the scenarios of integrated water resources management and planning. They defined the water resources sustainability index based on the performance criteria of time and volume reliability, resilience, vulnerability and maximum deficit. The results showed that reducing drinking, industry, and agriculture water, respectively, to $10 \%, 15 \%$, and $30 \%$, in line with the demand management scenario, and the implementation of Koohrang 3 and Behesht Abad plans in line with the scenario of supply management could improve or start improving the sustainability of water resources from weak mode to moderate to good. Yilmaz and Harmancioglu [21] used the WEAP model to evaluate water resource management in the Gediz River basin in Turkey. The initial input of the proposed model was the amount of surface water that is largely devoted to irrigation purposes. Therefore, the mutual relations of supply and demand in agricultural water consumption were the main focus of their study. The results of their study based on various indices such as sustainability index showed that Gediz River basin is completely sensitive to drought conditions and agricultural sector is significantly affected by irrigation deficit, especially in drought periods.

The main objective of this research was to evaluate the effects of future agricultural water management strategies under the influence of climate change on the inflow to the Urmia Lake and the agricultural condition during the years 2015-2040 using the WEAP21 model [22,23]. Considering that the Zarrinehrud and Siminehrud River basins are the largest sub-basins in the Urmia Lake basin, this research was carried out on these two sub-basins. The evaluation of the effects of these strategies was done by indices of environmental sustainability, agricultural sustainability, and irrigation water deficit.

\section{Materials and Methods}

\subsection{Study Area}

The Urmia Lake basin with an area of $51,876 \mathrm{~km}^{2}$ is located in the mountainous area of northwest of Iran and among West Azarbaijan provinces with $42 \%$ of the basin area, East Azarbaijan with 37\% of the basin area and Kurdestan with $11 \%$ of the basin area. Urmia Lake with an area of about $5100 \mathrm{~km}^{2}$ covers $10 \%$ of the basin area and is shared between the provinces of West Azerbaijan and East Azerbaijan [24]. Considering that Zarrinehrud and Siminehrud River basins provide about $52 \%$ of environmental flow requirements of Urmia Lake [25] and are among the main sub-basins of the Urmia Lake basin, this research is performed on these two sub-basins. Basin of Zarrinehrud-Siminehrud is located in the southern and southeastern parts of Lake Urmia and in terms of the size it is the largest sub-basin of Lake Urmia basin (Figure 1). 


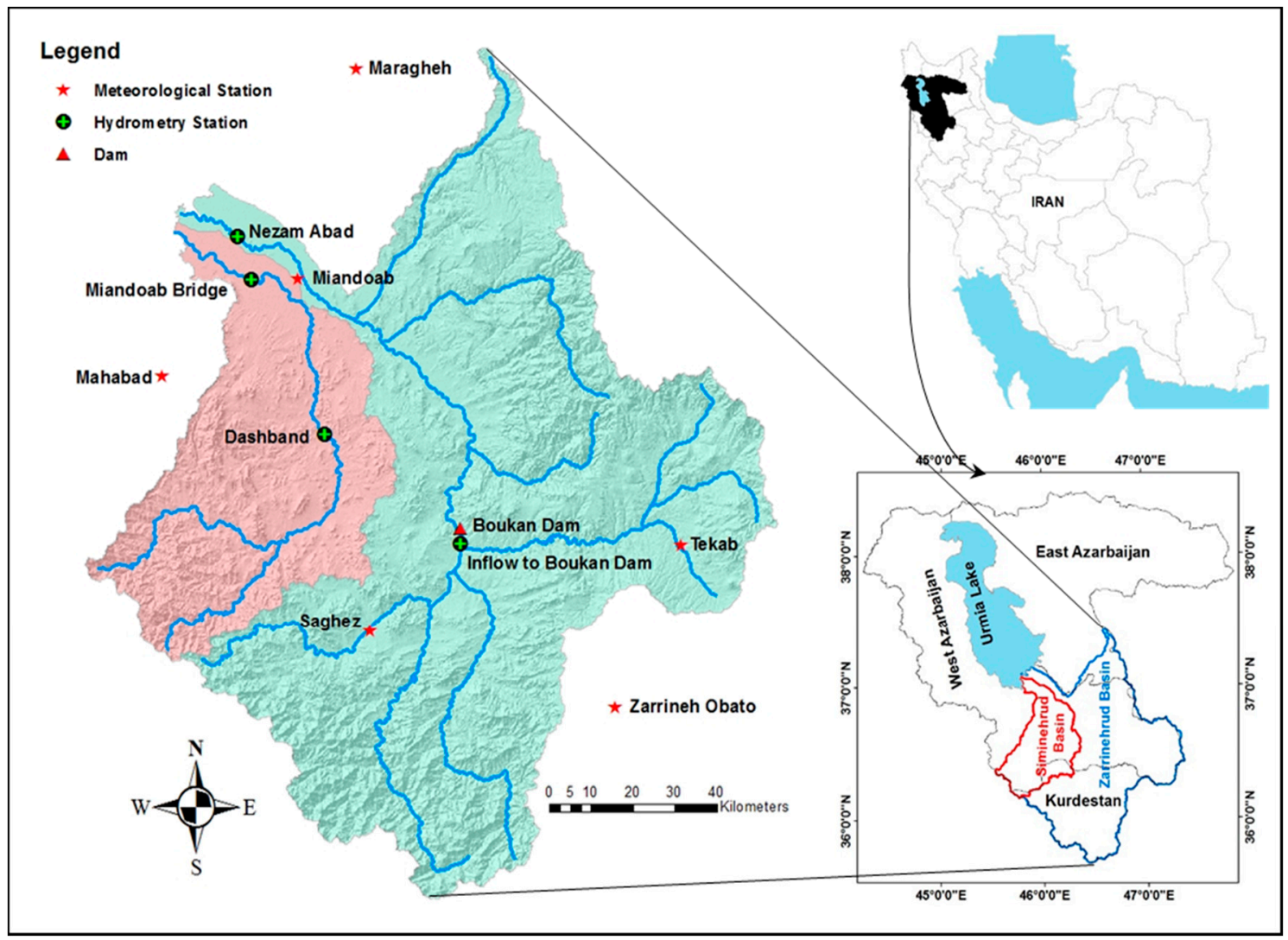

Figure 1. The map of the studied area.

The rivers of Zarrinehrud and Siminehrud with a maximum discharge of about 3 billion cubic meters per year in the period 1995-2014 are considered as water rich rivers in the country, which together with numerous natural and social potentials, have led to the development of agricultural activities in the watersheds of the basin. The length of Zarrinehrud River is about $240 \mathrm{~km}$ and the area of the basin is $11,840 \mathrm{~km}^{2}$. The length of Siminehrud River is roughly $200 \mathrm{~km}$ and the area of the basin is $3785 \mathrm{~km}^{2}$. The construction of irrigation networks such as Zarrinehrud (Miandoab), etc., and dams such as Shahid Kazemi Boukan dam with a reservoir volume of $810 \mathrm{MCM}$ have created facilities at the basin level, as a result of which about 136,000 hectares of the lands of the basin are cultivated by irrigation either traditionally or by modern methods.

\subsection{Introducing the WEAP Model}

WEAP is a modeling platform that can provide integrated assessment of climate, hydrology, land use, irrigation facilities, water allocation and water management priorities of the watershed. The WEAP model uses a standard linear programming model to solve water allocation problems at any time step and its target function is to maximize the percentage of supplying demand centers' needs, with regard to supply and demand priority, mass balance and other constraints. All constraints are defined intermittently for each step of time, with regard to the priority of supply and demand. The WEAP model calculates the mass balance equilibrium of water for each node and branch at either daily or monthly time steps [22,23]. Using the time series of the climate, the WEAP model calculates the hydrological cycle components by simulating the rainfall-runoff process at the surface of the catchment area [26]. In this study, the soil moisture method of WEAP model was used for modeling hydrological reaction of basins and inter-basins [27]. 


\subsection{Soil Moisture Method}

This one-dimensional, two-bucket soil moisture method is based on empirical functions that describe evapotranspiration, surface runoff, interflow, baseflow, and deep percolation for a basin unit (Figure 2). For a basin subdivided into several subbasins with different fractional land use or soil-type areas, the mathematical formulation to compute the storage change in the first layers is expressed in terms of a water balance as follows [28,29]:

$$
R d_{j} \frac{d z_{1, j}}{d t}=P_{e}(t)-\operatorname{PET}(t) k_{c, j}(t)\left(\frac{5 z_{1, j}-2 z_{1, j}^{2}}{3}\right)-P_{e}(t) z_{1, j}^{R R F_{j}}-f_{j} k_{s, j} z_{1, j}^{2}-\left(1-f_{j}\right) k_{s, j} z_{1, j}^{2}
$$

where $z_{1, j}$ is the relative soil water storage, a fraction of the total effective water storage in the root zone layer in area $j$ (dimensionless); $R d_{j}$ is the soil water holding capacity of the area $j(\mathrm{~mm}) ; P e$ is the effective precipitation $(\mathrm{mm}) ; P E T(t)$ is the reference potential evapotranspiration ( $\mathrm{mm} /$ day, potential evapotranspiration is derived using a Penman-Monteith formulation); $k_{c, j}$ is the crop coefficient for area $j$; and $R R F_{j}$ is the Runoff Resistance Factor of the land cover. Higher values of $R R F_{j}$ lead to less surface runoff. $P_{e}(t) z_{1, j}^{R R F_{j}}$ is the surface runoff; $f_{j} k_{s, j} z_{1, j}^{2}$ is the interflow from the first soil layer for area $j ; f_{j}$ is the partition coefficient related to the land cover type, soil, and topography for area $j$, which divides flow into horizontal $f_{j}$ and vertical $\left(1-f_{j}\right)$ flows; and $k_{s, j}$ is the saturated hydraulic conductivity of the root zone layer for area $j[\mathrm{~mm} /$ time $]$.

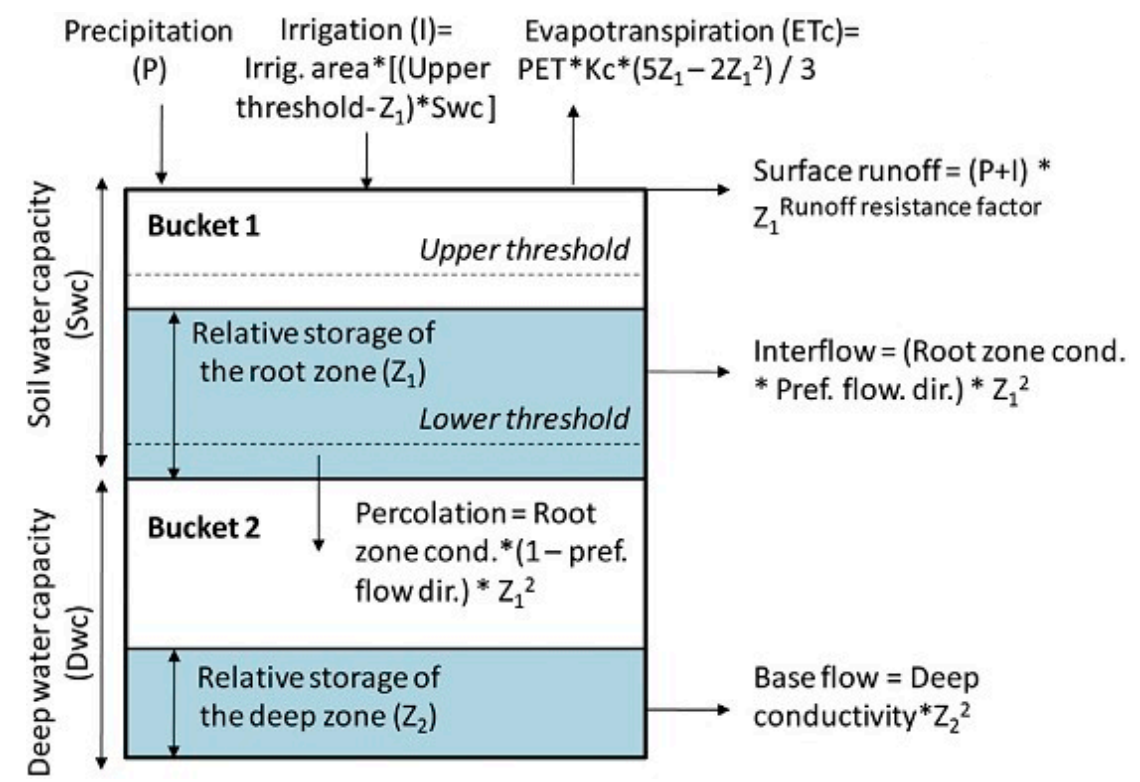

Figure 2. Conceptual diagram and equations incorporated in the soil moisture method [30].

The change of storage in the second layer $\left(d z_{2} / d t\right)$ is computed by:

$$
S_{\max } \frac{d z_{2}}{d t}=\left(\sum_{j=1}^{N}\left(1-f_{j}\right) k_{s, j} z_{1, j}^{2}\right)-k_{s 2} z_{2}^{2}
$$

where $S_{\max }$ is the deep percolation from the upper layer storage; and $k_{s 2}$ is the saturated hydraulic conductivity of the lower storage ( $\mathrm{mm} /$ time).

\subsection{Model Setup}

The model was developed for Zarrinehrud and Siminehrud River basins using WEAP21 software. The schematic of the model is shown in Figure 3. 


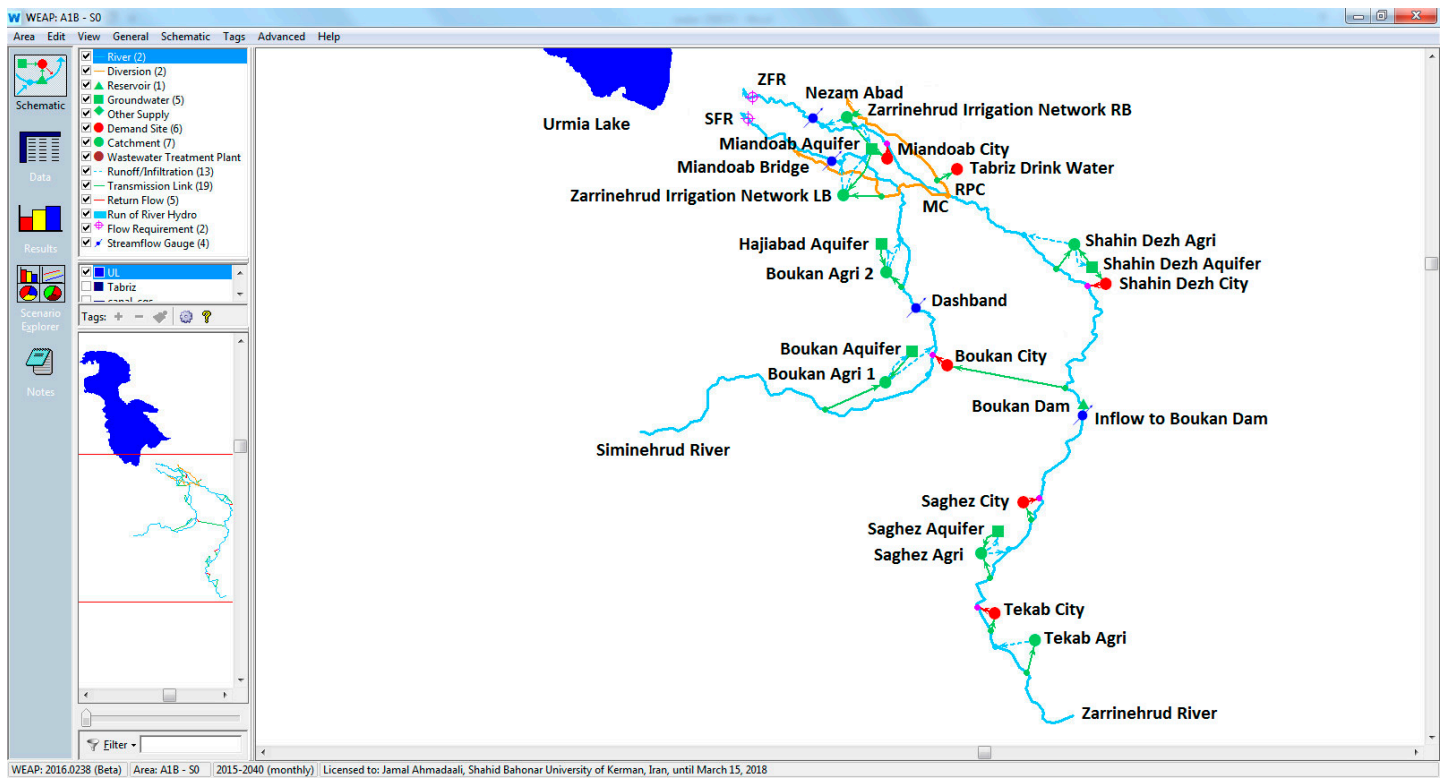

Figure 3. Schematic of WEAP model for Zarrinehrud and Siminehrud River basins.

This modeling includes:

- Two main rivers (Zarrinehrud and Siminehrud), two canals of water diversion (the right bank canal (RPC) and the Left bank canal (MC) of the Zarrinehrud irrigation network);

- One reservoir dam (Shahid Kazemi Boukan dam);

- Five aquifers (Saghez, ShahinDezh, Miandoab, Boukan, and Hajiabad);

- Six domestic demand points (Tekab, Saghez, Boukan, Shahin Dezh, Miandoab, and Tabriz (in the form of inter-basin conveyance from Zarrinehrud basin to Tabriz city with the capacity of about 150 MCM per year));

- Eleven catchments (four non-agriculture catchments including upstream and downstream of Zarrinehrud basin and upstream and downstream of Siminehrud basin, and seven agriculture catchments including Tekab, Saghez, Shahin Dezh, right bank and left bank of Zarrinehrud irrigation network, Boukan 1, and Boukan 2);

- Twenty-three lines of runoff/infiltration;

- Nineteen transmission links;

- Five return flows;

- Four hydrometric gauge stations (including the entrance of Boukan Dam and Nezam Abad located on the Zarrinehrud River and Dashband and Miandoab Bridge on the Siminehrud River); and

- Two points of the environmental flow requirements of Lake Urmia (from Zarrinehrud (ZFR) and Siminehrud (SFR) Rivers).

\subsection{Sources of Data and Information}

In this research, a 20-year period (1995-2014) was considered for calibration and validation of the model. Meteorological stations inside and near the basins studied were used for six synoptic stations of Zarrineh Obato, Tekab, Saghez, Mahabad, Miandoab, and Maragheh for meteorology parameters of precipitation, temperature, relative humidity, wind speed and cloudiness fraction. The mean of each of the meteorological parameters for each sub-basin was estimated using the Thiessen Polygons method. In the WEAP21 model, the basins of Zarrinehrud and Siminehrud were divided into upstream and downstream sub-basins according to the hydrometric gauge stations used. Zarrinehrud basin includes Tekab, Saghez, Shahin Dezh, and right bank and left bank of Zarrinehrud irrigation network and Siminehrud basin includes Boukan 1 and Boukan 2 agriculture catchments (Figure 3). 


\subsection{Calibration and Validation of the WEAP Model}

Calibration and validation of a model is necessary to minimize errors and to ensure the validity and reliability of the model results [17]. In this research, the model was calibrated by comparing the discharge data simulated in a monthly scale with observation data at selected hydrometric gauge stations. An 11-year period (from water year 1994-1995 to 2004-2005) was used to calibrate the model and a period of nine years (from water year 2005-2006 to 2013-2014) was used to validate the model.

In this study, to simulate flow discharge data, the parameters of non-agricultural crop coefficient, soil water capacity, root zone conductivity and preferred flow direction were calibrated using PEST (Parameter Estimation) [28]. The values of non-calibrated parameters were selected based on spatial and temporal conditions and the default values of the model. During this process, the flow simulated by the model was compared to the flow observed in the selected hydrometric gauge stations.

For quantitative evaluation of the results of calibration and validation of the model, Pearson's correlation coefficient, Nash-Sutcliffe Efficiency (NSE) and Index of Agreement (d) were used. The relations of the Nash-Sutcliffe Efficiency and Index of Agreement are as follows [31,32].

$$
\begin{gathered}
N S E=1-\left[\frac{\sum_{i=1}^{n}\left(Q_{i}^{o b s}-Q_{i}^{s i m}\right)^{2}}{\sum_{i=1}^{n}\left(Q_{i}^{o b s}-Q_{o b s}^{\text {mean }}\right)^{2}}\right] \\
d=1-\frac{\sum_{i=1}^{n}\left(Q_{i}^{o b s}-Q_{i}^{s i m}\right)^{2}}{\sum_{i=1}^{n}\left(\left|Q_{i}^{\text {sim }}-Q_{o b s}^{\text {mean }}\right|+\left|Q_{i}^{\text {obs }}-Q_{o b s}^{\text {mean }}\right|\right)^{2}}
\end{gathered}
$$

where $Q_{i}^{o b s}$ is the observed discharge for the $i$ th period, $Q_{o b s}^{\text {mean }}$ is the mean of the observed discharge for the entire period, $Q_{i}^{s i m}$ is the simulated discharge for the $i$ th period, and $\mathrm{n}$ is the total number of data.

\subsection{Climate Change}

To investigate the effect of climate change on water resources of the basins, the HadCM3 climatic model was used under the emission scenarios A2, A1B and B1 based on the IPCC (Intergovernmental Panel on Climate Change, Geneva, Switzerland) [33] for the period 2015-2040. SRES A2, A1B and B1 have a similar trajectory to RCP8.5, RCP6.0 and RCP4.5, respectively [34]. The output of climatologic models does not have the spatial and temporal analysis accuracy required for hydrologic models, therefore, it is necessary to downscale the output of climatic models for the region in question. In this research, the LARS-WG model was used to downscale the data. The inputs of this model are minimum and maximum daily temperature, daily precipitation and daily sunshine hours [35]. The baseline period in this study was 1986-2010 for six synoptic stations of Zarrineh Obato, Tekab, Saghez, Mahabad, Miandoab, and Maragheh. The model was evaluated by comparing baseline data and data generated by the model using RMSE, MSE, MAE, $\mathrm{R}^{2}$, Bias and NSE. After evaluating the performance of the LARS-WG model using the relevant indices and ensuring the suitability of the model, data for the period 2015-2040 were generated. After data generation for the upcoming period from rainfall, minimum temperature and maximum temperature, the monthly means of these parameters were calculated for the upcoming period (2015-2040). Then, their changes were calculated relative to the mean values of the baseline period and the temperature and precipitation diagrams were plotted for each of the stations.

Because LARS-WG is a stochastic weather generator, it was run 100 times for each emission scenario. These 100 realizations per emission scenario were used in the WEAP model for computing water fluxes which were averaged afterwards. Although Guo et al. [36] concluded that 25 realizations are sufficient and there is no significant difference between 25 and 100 realizations, we followed the recommendation of the LARS-WG manual. 


\subsection{Evaluation of the Impact of Climate Change to the Hydrological Component Using the WEAP Model}

To analyze the future impact of climate change on streamflow and ET, the WEAP model is used for the hydrological processes using the A2, A1B and B1 climate projection from the HadCM3 and LARS-WG.

To quantify the change in hydrology of the basin as an impact of climate change, the comparison of streamflow and ET in baseline period and future emission scenarios is performed [37]. To determine the baseline conditions, the validated WEAP model was used to generate the streamflow and ET in the Zarrinehrud and Siminehrud River basins during the period 1986-2010. Similar steps were applied to generate the streamflow and ET during future period (2015-2040) using downscaled temperature and precipitation corresponding to $\mathrm{A} 2, \mathrm{~A} 1 \mathrm{~B}$ and $\mathrm{B} 1$ climate projections.

\subsection{Developing Scenarios}

In this research, scenarios have been developed based on management strategies and future climate change. The main goal of the management strategies is to increase water supply, increase irrigation efficiency or reduce agricultural water demand, so that the saved water can be allocated to Urmia Lake and increase its sustainability. To develop future climate scenarios, outputs of rainfall and temperature downscaled by the LARS-WG model for the HadCM3 general circulation model (GCM) for the three emission scenarios of A2, A1B and B1 for the period 2015-2040 were used.

Specifications of agriculture catchments for the current account (2015) is described in Table 1.

Table 1. Specifications of agriculture catchments in the current account (2015) [38-40].

\begin{tabular}{|c|c|c|c|c|c|}
\hline Basin & $\begin{array}{l}\text { Agriculture } \\
\text { Catchment }\end{array}$ & Area (ha) & $\begin{array}{c}\text { Dominant Crop } \\
\text { Pattern }\end{array}$ & Irrigation Systems (\%) & $\begin{array}{l}\text { Irrigation } \\
\text { Efficiency }\end{array}$ \\
\hline \multirow{2}{*}{ Siminehrud } & Boukan 1 & 15,000 & $\begin{array}{l}\text { Wheat, Sugar beet, } \\
\text { Alfalfa, Apple }\end{array}$ & $\begin{array}{l}\text { Surface (58.1), Sprinkler } \\
\text { (40.7), Drip (1.2) }\end{array}$ & 0.5 \\
\hline & Boukan 2 & 10,000 & $\begin{array}{l}\text { Wheat, Sugar beet, } \\
\text { Alfalfa, Apple }\end{array}$ & $\begin{array}{l}\text { Surface (49), Sprinkler } \\
\text { (50.3), Drip (0.7) }\end{array}$ & 0.52 \\
\hline \multirow{5}{*}{ Zarrinehrud } & Saghez & 16,000 & $\begin{array}{l}\text { Alfalfa, Wheat, } \\
\text { Barely, Sugar beet, } \\
\text { Apple }\end{array}$ & $\begin{array}{l}\text { Surface (65.8), Sprinkler } \\
\text { (32.4), Drip (1.8) }\end{array}$ & 0.43 \\
\hline & Tekab & 13,000 & $\begin{array}{l}\text { Alfalfa, Apple, } \\
\text { Wheat }\end{array}$ & $\begin{array}{c}\text { Surface (95.2), Sprinkler } \\
\text { (3), Drip (1.8) }\end{array}$ & 0.35 \\
\hline & Shahin Dezh & 32,000 & $\begin{array}{l}\text { Wheat, Alfalfa, } \\
\text { Barely, Sugar beet, } \\
\text { Apple }\end{array}$ & $\begin{array}{l}\text { Surface (86.5), Sprinkler } \\
\text { (12), Drip (1.5) }\end{array}$ & 0.36 \\
\hline & $\mathrm{ZRB}^{1}$ & 25,500 & $\begin{array}{l}\text { Wheat, Alfalfa, } \\
\text { Grape, Apple, } \\
\text { Sugar beet }\end{array}$ & $\begin{array}{l}\text { Surface (94.9), Sprinkler } \\
\text { (4.9), Drip }(0.2)\end{array}$ & 0.44 \\
\hline & $\mathrm{ZLB}^{2}$ & 24,500 & $\begin{array}{l}\text { Wheat, Alfalfa, } \\
\text { Grape, Apple, } \\
\text { Sugar beet }\end{array}$ & $\begin{array}{c}\text { Surface (90.6), Sprinkler } \\
\text { (9), Drip (0.4) }\end{array}$ & 0.43 \\
\hline
\end{tabular}

Notes: ${ }^{1}$ Zarrinehrud Irrigation Network (Right Bank). ${ }^{2}$ Zarrinehrud Irrigation Network (Left Bank).

Selected scenarios are combination of management strategies and climate change as follows:

(1) Base scenario (S0)

The base scenario is based on a future climate prediction (A2, A1B, and B1). The cropped area and future crop pattern are considered constant for the base scenario and are equal to 2014 data. However, domestic water demand varied according to the predicted population growth rate and will be applied to all other scenarios. 


\section{(2) Scenario $1(\mathrm{~S} 1)$}

$\mathrm{S} 1$ is a combination of climate change and a change in the present crop pattern with crops which have lower water requirements. In this scenario, high-consumption crops of alfalfa and sugar beets will be replaced by low-consumption wheat, barley and rapeseed. In each agriculture catchment, a small amount of alfalfa cultivation will not change to provide local requirement.

\section{(3) Scenario 2 (S2)}

S2 combines climate change and improvement of conveyance and distribution efficiency by $15 \%$ of present status to reduce water losses. In this scenario, improvements in conveyance and distribution efficiency will be achieved through rehabilitation of the Zarrinehrud irrigation network, dredging and canal lining, water conveyance through pipelines, and education and technical support for farmers.

\section{(4) Scenario 3 (S3)}

S3 is a combination of S2 and improving application efficiency by changing the systems of surface irrigation to sprinkler and drip irrigation. In this scenario, the application efficiency of sprinkler irrigation system is considered as $75 \%$ and the application efficiency of drip irrigation system is considered as $95 \%$.

\section{(5) Scenario $4(\mathrm{~S} 4)$}

S4 is a combination of S1 and S3. In this scenario, in addition to changing the crop pattern to lower-consumption crops, the conveyance, distribution, and application efficiency (total irrigation efficiency) also increased.

\subsection{Evaluation Indicators}

To assess the considered scenarios, Environmental Sustainability Index (ESI), Agricultural Sustainability Index (ASI) and Irrigation Water Deficit (IWD) were considered (Table 2).

Table 2. Evaluation indicator [21].

\begin{tabular}{ll}
\hline \multicolumn{1}{c}{ Indicator } & \multicolumn{1}{c}{ Description } \\
\hline Environmental Sustainability Index (ESI) & $\begin{array}{l}\text { The temporal aggregation of supply/demand ratio time series (only } \\
\text { for environmental flow requirements) based on performance criteria } \\
\text { when satisfactory value is equal to } 1 \text { (full coverage) }\end{array}$ \\
\hline Agricultural Sustainability Index (ASI) & $\begin{array}{l}\text { The temporal aggregation of supply/demand ratio time series (for } \\
\text { irrigation only) based on performance criteria when satisfactory } \\
\text { value is considered between 0.8 and 1 }\end{array}$ \\
\hline Irrigation Water Deficit (IWD) & $\begin{array}{l}\text { Indicates annual unmet demand for irrigation (annual mean value is } \\
\text { used in evaluations); } 10^{6} \mathrm{~m}^{3}\end{array}$ \\
\hline
\end{tabular}

ESI is used for assessing the status of providing the environmental flow requirements (EFRs) of Urmia Lake from the basins of Zarrinehrud and Siminehrud and indicators of agricultural sustainability and irrigation water deficit are used to evaluate the irrigation status of the Zarrinehrud and Siminehrud basins.

\subsubsection{Performance Criteria}

The sustainability index (SI) is calculated by integrating the reliability, resilience and vulnerability performance criteria.

Performance criteria are defined as follows [41,42]: 
Reliability (Rel)

Reliability is defined as the probability of any specific $C_{t}$ value, whose $C_{t}$ is time series of any selected indicator $C$, within the range of satisfactory values as follows:

$$
\operatorname{Rel}(C)=\frac{\text { Number of satisfactory values }}{\text { Total number of simulation period }}
$$

Resilience (Res)

Resilience is a criterion for describing the rate of recovery from an unsatisfactory condition. It is the probability of occurrence of a satisfactory $C_{t+1}$ value following an unsatisfactory $C_{t}$ value and is defined as follows:

$$
\operatorname{Res}(C)=\frac{\text { Number of times a satisfactory value occurs after an unsatisfactory value }}{\text { Total number unsatisfactory values }}
$$

Vulnerability (Vul)

Vulnerability is a statistical measure of size (magnitude) or duration of failures in a given time series. The size (magnitude) of a failure is a value where a $C_{t}$ exceeds the upper limit of satisfactory values $\left(\mathrm{UL}\left(\mathrm{C}_{t}\right)\right)$, or below the lower limit of satisfactory values $\left(\operatorname{LL}\left(\mathrm{C}_{t}\right)\right)$. In this research, vulnerability is defined as the expected extent-vulnerability, in which the duration of failures is eliminated and defined as follows:

$$
\operatorname{Vul}(C)=\frac{\text { Total individual extents of failure }}{\text { Total number of individual extents of failures }}
$$

In the above equations, a satisfactory value is the "supply/demand ratio" that for environmental flow requirements is equal to 1 (full coverage) and for irrigation is considered between 0.8 and 1 . Other values are considered as unsatisfactory values.

\subsubsection{Sustainability Index (SI)}

Sustainability is a relatively new concept for measuring the performance of water resource systems over long periods [43]. This index is proposed to facilitate the assessment of a water management policy and to compare it to other policies [44]. The sustainability index changes from 0 for the lowest and the worst possible value up to 1 for the highest and best possible value [21]. In this research, the sustainability index is calculated as Equation (8). This index assures the properties of the SI defined by Loucks [39], but also has the following improvements: Content, Scaling, and Flexibility [45]. ESI and ASI are calculated based on Equation (8) with Equations (9) and (10).

$$
\mathrm{SI}^{i}=\left[\operatorname{Rel}^{i} * \operatorname{Res}^{i} *\left(1-\operatorname{Vul}^{i}\right)\right]^{\frac{1}{3}}
$$

In Equation (8), Rel, Res and Vul are Reliability, Resilience and Vulnerability, respectively.

$$
\begin{aligned}
& \mathrm{ESI}=\left[\operatorname{Rel}_{\left(\frac{\mathrm{Se}}{\mathrm{De}}\right)} * \operatorname{Res}_{\left(\frac{\mathrm{Se}}{\mathrm{De}}\right)} *\left(1-\operatorname{Vul}_{\left(\frac{\mathrm{Se}}{\mathrm{De}}\right)}\right)\right]^{\frac{1}{3}} \\
& \mathrm{ASI}=\left[\operatorname{Rel}_{\left(\frac{\mathrm{Sa}}{\mathrm{Da}}\right)} * \operatorname{Res}_{\left(\frac{\mathrm{Sa}}{\mathrm{Da}}\right)} *\left(1-\operatorname{Vul}_{\left(\frac{\mathrm{Sa}}{\mathrm{Da}}\right)}\right)\right]^{\frac{1}{3}}
\end{aligned}
$$

The index used for ESI is supply/demand ratio (Se/De) of Urmia Lake, in which demand is Urmia Lake's environmental flow requirements (EFRs) and the index used for ASI is supply/demand ratio (Sa/Da) of agriculture catchments for reliability, resilience and vulnerability performance criteria.

For a group comparison of water users, sustainability based on the group (SG) was defined as the weighted average of sustainability indices. SG is used to calculate the sustainability for a group $k$ with water users from $i$ to $j$ belonging to this group [45]. 


$$
\mathrm{SG}^{k}=\sum_{i=1 \in k}^{i=j \in k} \mathrm{~W}^{i} * \mathrm{SI}^{i}
$$

In Equation (11), $\mathrm{W}^{i}$ is relative weight for the $i$ th water user, which varies between 0 and 1 and the sum is equal to 1 . In this study, the water users are equal to the agriculture catchments $(i)$ and the $k$ group is Zarrinehrud and Siminehrud basins. For Zarrinehrud basin, $j=5$ (number of agriculture catchments) and for Siminehrud basin, $j=2$ (number of agriculture catchments).

If SI for each water user is weighted by its annual water demand, SG for the $k$ th group is defined as follows:

$$
\mathrm{SG}^{k}=\sum_{i=1 \in k}^{i=j \in k} \frac{\text { Waterdemand }^{i}}{\text { Waterdemand }^{k}} * \mathrm{SI}^{i}
$$

in which:

$$
\text { Water demand }^{k}=\sum_{i=1 \in k}^{i=j \in k} \text { Water demand }{ }^{i}
$$

\subsection{Environmental Flow Requirements (EFRs) of Urmia Lake}

Abbaspour and Nazaridoost [46] determined the environmental flow requirements of Urmia Lake using an ecological approach. The three variables of ecology, water quality and water quantity were considered as environmental indicators to calculate the lake environmental flow requirements using the ecological approach. The salinity threshold of $240 \mathrm{ppt}$ is considered as the water quality requirement for Artemia Urmiana. The aggregation of these variables showed that Urmia Lake requires about 3100 MCM of water flow per year for a sustainable ecosystem, which is equivalent to the ecological level of the lake water level (1274.1 m.a.s.l.).

In addition, based on long-term historical data, the Zarrinehrud basin provides about $41 \%$ and the Siminehrud basin provides about $11 \%$ of the Urmia Lake's environmental flow requirement [25]. Therefore, the share of supplying the Urmia Lake's environmental flow requirements from the Zarrinehrud and Siminehrud basins is estimated as 1271 and 341 MCM per year, respectively.

\section{Results and Discussion}

\subsection{Performance of Models in the Historical Period}

\subsubsection{WEAP Model of the Study Area}

The monthly simulated discharge by the WEAP model is in good agreement with the observed discharge in the hydrometric gauge stations of the entrance of Boukan Dam, Nezam Abad, Dashband and Miandoab Bridge (Figure 4). The values of the correlation coefficient indices, Nash-Sutcliffe Efficiency (NSE) and Index of Agreement (d) are also shown in Figure 4.

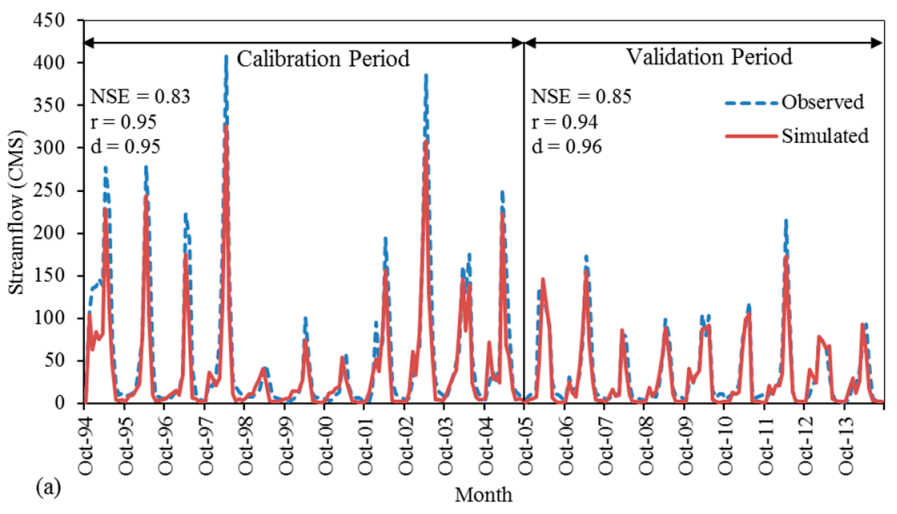

Figure 4. Cont. 

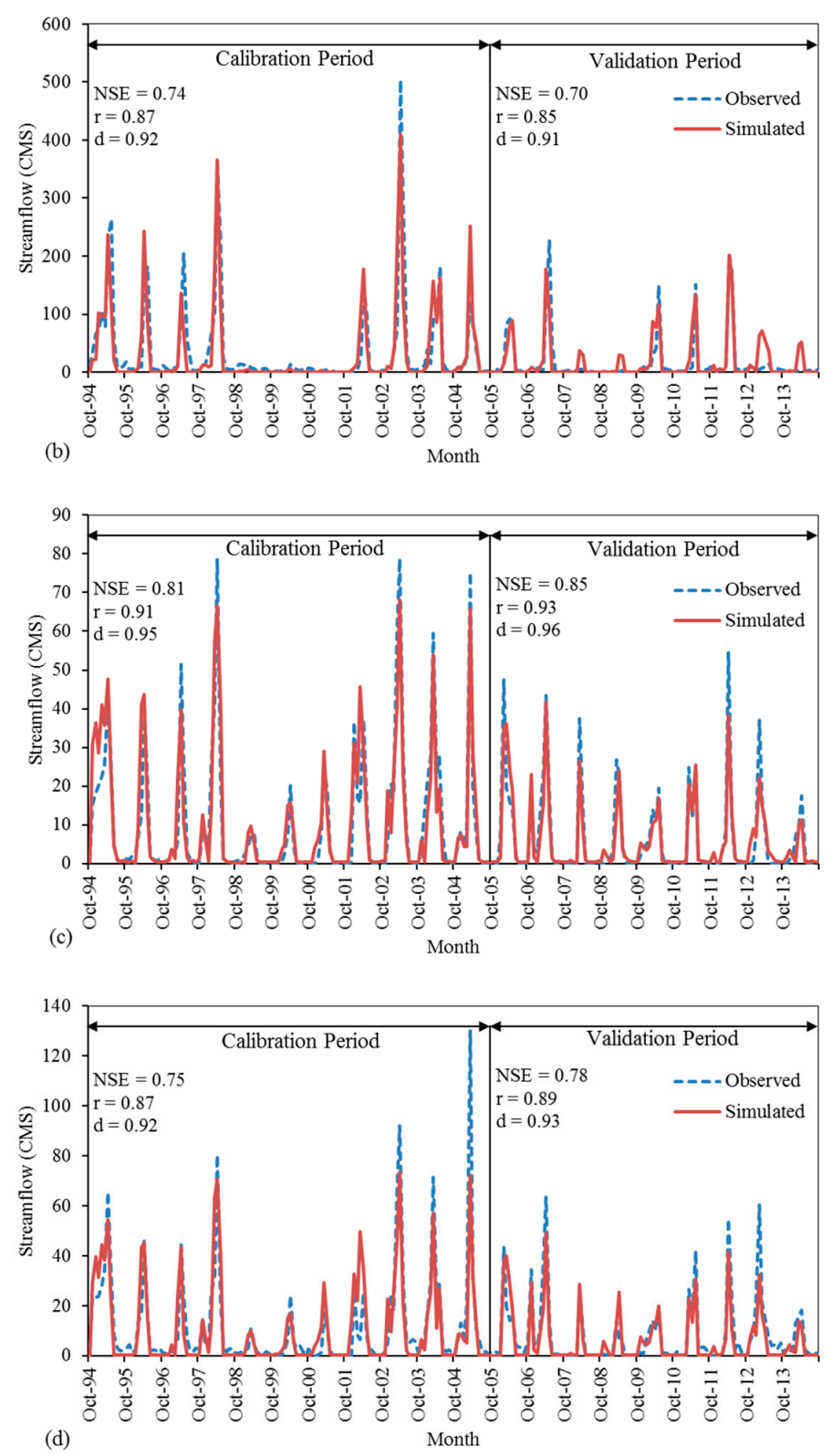

Figure 4. Observational and simulated monthly discharges for calibration and validation periods at hydrometry stations: (a) entrance of Boukan Dam; (b) Nezam Abad; (c) Dashband; and (d) Miandoab Bridge.

In general, it can be said that the agreement between observed and simulated values both in the calibration period and in the validation period is good with respect to the indices and using the WEAP21 model is recommended for water resource planners to simulate and evaluate the different scenarios.

\subsubsection{Precipitation and Temperature}

The results of the comparison of the average monthly precipitation and temperature observations and those simulated using the LARS-WG model based on the relevant indices for the Zarrineh Obato station are shown in Table 3. For Tekab, Saghez, Mahabad, Miandoab and Maragheh stations, the indices of RMSE, MSE, MAE, ${ }^{2}$, BIAS and NSE for Precipitation were between 2.53 and 4.73, 6.38 and $22.41,2.07$ and $3.66,0.96$ and $0.99,-2.08$ and 0.38 , and 0.94 and 0.99 , respectively; for Tmin, they were between 0.16 and $0.26,0.03$ and $0.07,0.13$ and $0.22,0.99$ and -0.06 , and 0.04 and 0.99 , respectively; and, for Tmax, they were between 0.24 and $0.38,0.06$ and $0.14,0.21$ and $0.27,0.99$ and 0.04 , and 0.1 and 0.99 , respectively. The results show that the model is well able to make possible changes in the future according to the future climate scenarios. 
Table 3. Performance evaluation of the LARS-WG model in the basic period using different indices.

\begin{tabular}{cccccccc}
\hline Station & Parameter & RMSE & MSE & MAE & $\mathbf{R}^{\mathbf{2}}$ & BIAS & NSE \\
\hline \multirow{2}{*}{ Zarrineh } & Precipitation & 4.78 & 22.86 & 3.52 & 0.97 & -0.32 & 0.96 \\
Obato & Tmin & 0.24 & 0.06 & 0.2 & 0.99 & 0.01 & 0.99 \\
& Tmax & 0.24 & 0.06 & 0.19 & 0.99 & 0.01 & 0.99 \\
\hline
\end{tabular}

\subsection{Future Climate}

The average annual precipitation, and minimum and maximum temperature for the studied stations for the base period (1986-2010) and the future period (2015-2040) are shown in Figures 5 and 6. The precipitation of the studied stations in the future period is increasing for all emissions scenarios as compared to the base period. Most precipitation of emission scenarios for all stations is related to the B1 emission scenario and the lowest amount to the A2 emission scenario. In addition, the minimum and maximum temperature of the studied stations in the future period will increase for all emission scenarios as compared to the base period.

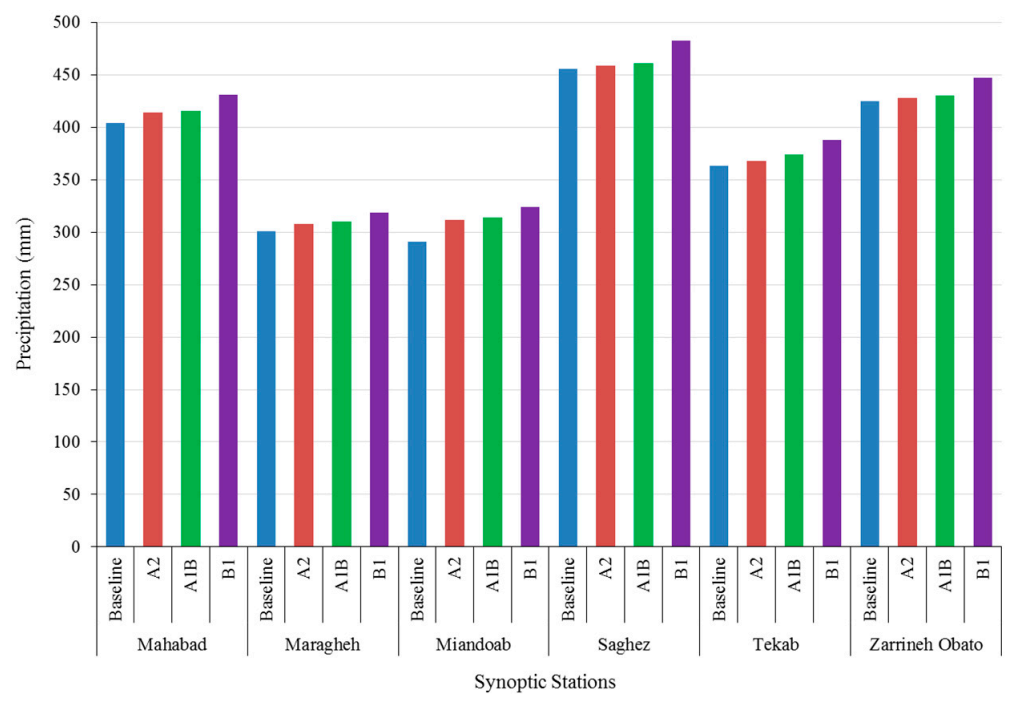

Figure 5. Comparison of mean precipitation of the studied stations in the future period (2015-2040) under different emission scenarios as compared to the baseline period (1986-2010).

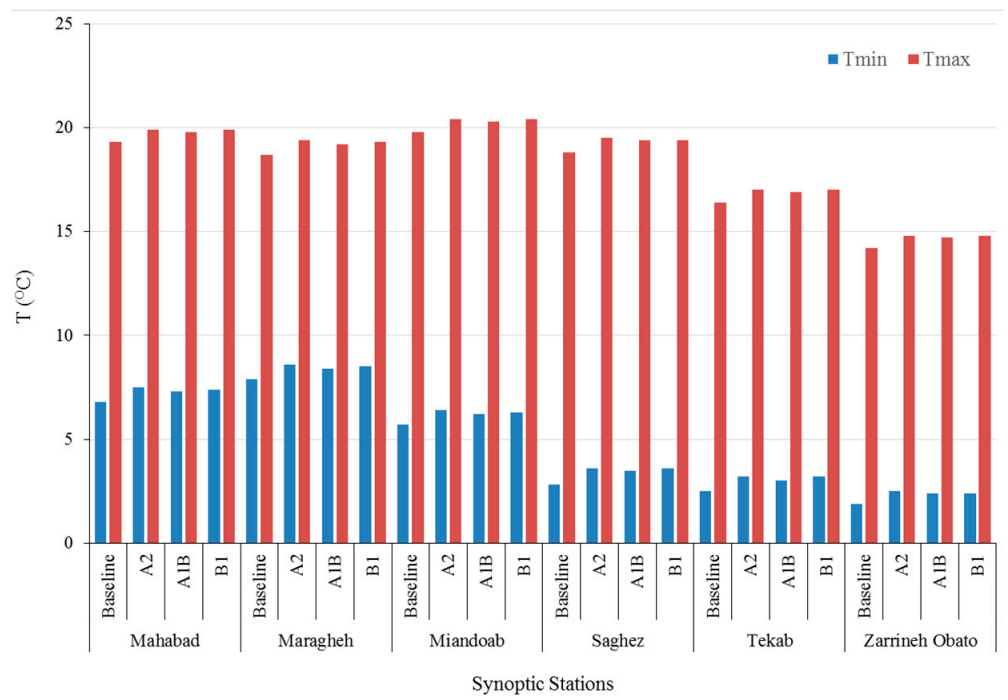

Figure 6. Comparison of mean minimum and maximum temperature of the studied stations in the future period (2015-2040) under different emission scenarios as compared to the baseline period (1986-2010). 


\subsection{Impact of Climate Change on the Hydrology in the Study Area}

\subsubsection{Change in Streamflow}

Figure 7 shows the projected changes of the average annual streamflow in the future period (2015-2040) under A2, A1B and B1 emission scenarios compared with the baseline period (1986-2010) for Zarrinehrud and Siminehrud River basins. As shown in Figure 7, streamflow is projected to decrease in the future for all emission scenarios in comparison with the baseline period.

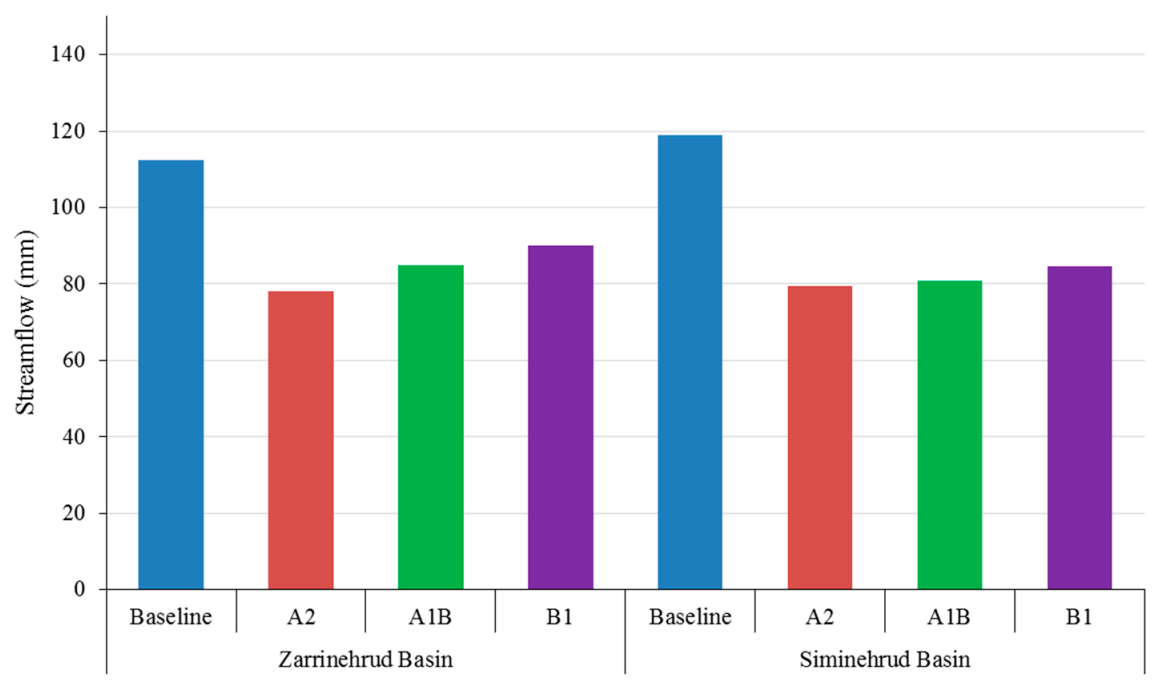

Figure 7. Comparison of mean streamflow in the future period (2015-2040) under different emission scenarios as compared to the baseline period (1986-2010).

\subsubsection{Change in Actual Evapotranspiration (ETc)}

The result of the ETc analysis shows that the average annual ETc under the all emission scenarios is projected to increase compared to the baseline period (Figure 8).

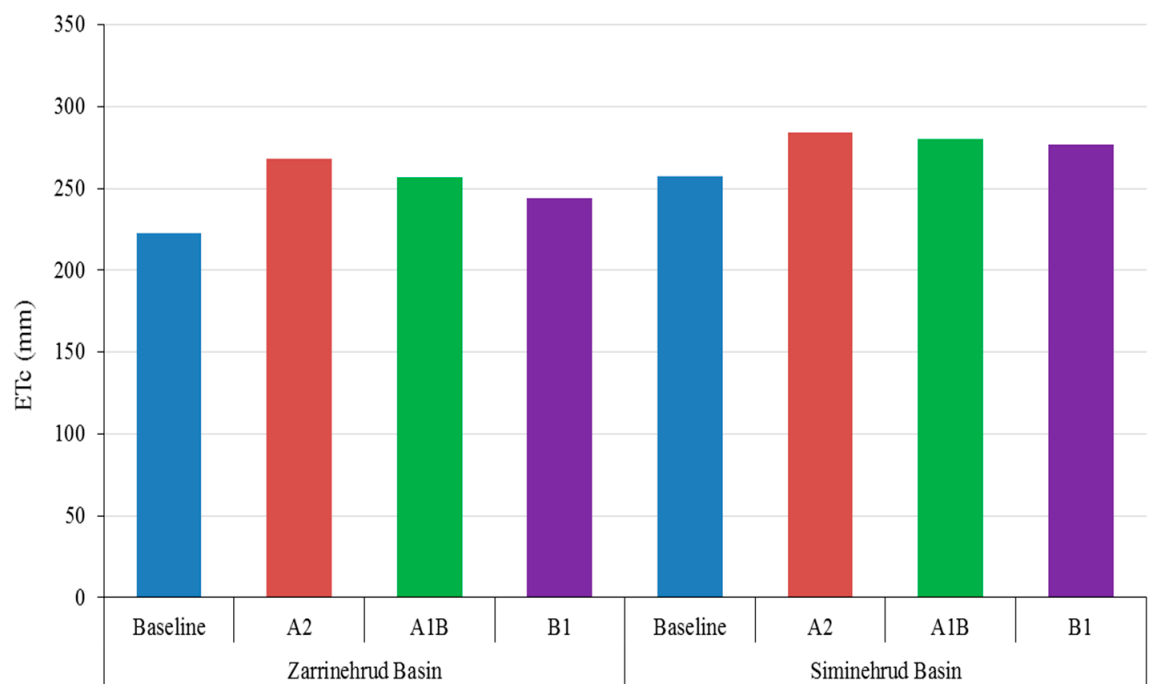

Figure 8. Comparison of mean actual evapotranspiration (ETc) in the future period (2015-2040) under different emission scenarios as compared to the baseline period (1986-2010).

In this study, precipitation and temperature are projected to increase in the future. Potential ET increase due to increase in temperature which results in an increase in actual ET (ETc). As the ETc increases in the future, the streamflow decreases since the increase in ETc will be more than the increase in precipitation. 


\subsection{Evaluation of Scenarios}

\subsubsection{Performance Criteria}

Performance criteria of reliability, resilience and vulnerability for agriculture catchments are presented in Table 4. The highest increase for reliability and resilience and highest decrease for vulnerability for all agriculture catchments is related to S4, or the crop pattern change with increasing irrigation efficiency. According to Table 4, the implementation of water management scenarios has increased reliability and resilience and reduced vulnerability.

Table 4. Performance criteria of reliability, resilience and vulnerability for agriculture catchments.

\begin{tabular}{|c|c|c|c|c|c|c|c|c|c|c|c|c|c|c|c|}
\hline \multirow{2}{*}{ Scenario } & \multicolumn{3}{|c|}{ So } & \multicolumn{3}{|c|}{ S1 } & \multicolumn{3}{|c|}{ S2 } & \multicolumn{3}{|c|}{ S3 } & \multicolumn{3}{|c|}{ S4 } \\
\hline & $\operatorname{Rel}^{1}$ & $\operatorname{Res}^{2}$ & $\mathrm{Vul}^{3}$ & Rel & Res & Vul & Rel & Res & Vul & Rel & Res & Vul & Rel & Res & Vul \\
\hline \multicolumn{16}{|l|}{$\mathrm{A} 2$} \\
\hline Boukan 1 & 0.69 & 0.65 & 0.07 & 0.72 & 0.67 & 0.06 & 0.71 & 0.66 & 0.06 & 0.74 & 0.68 & 0.05 & 0.78 & 0.71 & 0.04 \\
\hline Boukan 2 & 0.72 & 0.65 & 0.06 & 0.75 & 0.67 & 0.05 & 0.73 & 0.66 & 0.06 & 0.75 & 0.7 & 0.05 & 0.81 & 0.71 & 0.04 \\
\hline Saghez & 0.6 & 0.54 & 0.19 & 0.68 & 0.63 & 0.13 & 0.63 & 0.57 & 0.16 & 0.7 & 0.65 & 0.11 & 0.75 & 0.68 & 0.07 \\
\hline Tekab & 0.41 & 0.33 & 0.36 & 0.57 & 0.48 & 0.21 & 0.49 & 0.41 & 0.26 & 0.59 & 0.5 & 0.19 & 0.67 & 0.58 & 0.11 \\
\hline $\begin{array}{c}\text { Shahin } \\
\text { Dezh }\end{array}$ & 0.54 & 0.47 & 0.23 & 0.62 & 0.55 & 0.15 & 0.58 & 0.51 & 0.19 & 0.64 & 0.57 & 0.13 & 0.73 & 0.66 & 0.05 \\
\hline ZRB & 0.73 & 0.67 & 0.06 & 0.76 & 0.71 & 0.05 & 0.74 & 0.68 & 0.06 & 0.79 & 0.74 & 0.05 & 0.81 & 0.76 & 0.04 \\
\hline ZLB & 0.71 & 0.66 & 0.06 & 0.75 & 0.69 & 0.05 & 0.72 & 0.67 & 0.06 & 0.78 & 0.72 & 0.05 & 0.8 & 0.74 & 0.04 \\
\hline \multicolumn{16}{|l|}{ A1B } \\
\hline Boukan 1 & 0.72 & 0.65 & 0.06 & 0.74 & 0.68 & 0.05 & 0.73 & 0.66 & 0.06 & 0.77 & 0.7 & 0.04 & 0.8 & 0.72 & 0.04 \\
\hline Boukan 2 & 0.72 & 0.67 & 0.06 & 0.75 & 0.69 & 0.04 & 0.74 & 0.68 & 0.05 & 0.78 & 0.71 & 0.04 & 0.82 & 0.73 & 0.04 \\
\hline Saghez & 0.61 & 0.55 & 0.17 & 0.69 & 0.64 & 0.11 & 0.64 & 0.58 & 0.15 & 0.72 & 0.66 & 0.1 & 0.76 & 0.69 & 0.06 \\
\hline Tekab & 0.42 & 0.34 & 0.35 & 0.59 & 0.48 & 0.19 & 0.5 & 0.42 & 0.25 & 0.61 & 0.51 & 0.18 & 0.69 & 0.58 & 0.1 \\
\hline $\begin{array}{c}\text { Shahin } \\
\text { Dezh }\end{array}$ & 0.55 & 0.48 & 0.21 & 0.63 & 0.56 & 0.14 & 0.59 & 0.52 & 0.18 & 0.65 & 0.57 & 0.11 & 0.75 & 0.67 & 0.05 \\
\hline ZRB & 0.74 & 0.68 & 0.06 & 0.77 & 0.72 & 0.05 & 0.76 & 0.71 & 0.05 & 0.8 & 0.75 & 0.05 & 0.83 & 0.77 & 0.04 \\
\hline ZLB & 0.73 & 0.66 & 0.06 & 0.76 & 0.7 & 0.05 & 0.76 & 0.68 & 0.05 & 0.79 & 0.73 & 0.05 & 0.81 & 0.76 & 0.04 \\
\hline \multicolumn{16}{|l|}{ B1 } \\
\hline Boukan 1 & 0.72 & 0.67 & 0.06 & 0.76 & 0.71 & 0.04 & 0.75 & 0.69 & 0.04 & 0.8 & 0.72 & 0.04 & 0.83 & 0.74 & 0.03 \\
\hline Boukan 2 & 0.75 & 0.67 & 0.05 & 0.77 & 0.72 & 0.04 & 0.76 & 0.71 & 0.04 & 0.83 & 0.72 & 0.04 & 0.85 & 0.75 & 0.03 \\
\hline Saghez & 0.64 & 0.56 & 0.16 & 0.71 & 0.67 & 0.1 & 0.67 & 0.6 & 0.13 & 0.74 & 0.67 & 0.08 & 0.78 & 0.72 & 0.05 \\
\hline Tekab & 0.44 & 0.36 & 0.33 & 0.61 & 0.51 & 0.18 & 0.52 & 0.43 & 0.22 & 0.63 & 0.52 & 0.16 & 0.71 & 0.6 & 0.08 \\
\hline $\begin{array}{l}\text { Shahin } \\
\text { Dezh }\end{array}$ & 0.57 & 0.5 & 0.2 & 0.65 & 0.58 & 0.12 & 0.61 & 0.54 & 0.16 & 0.67 & 0.59 & 0.09 & 0.77 & 0.69 & 0.04 \\
\hline ZRB & 0.77 & 0.7 & 0.05 & 0.79 & 0.76 & 0.04 & 0.8 & 0.73 & 0.05 & 0.8 & 0.77 & 0.04 & 0.85 & 0.79 & 0.02 \\
\hline ZLB & 0.77 & 0.67 & 0.05 & 0.78 & 0.74 & 0.05 & 0.77 & 0.73 & 0.05 & 0.81 & 0.73 & 0.04 & 0.83 & 0.79 & 0.03 \\
\hline
\end{tabular}

Performance criteria of reliability, resilience and vulnerability for Zarrinehrud and Siminehrud River basins in connection with the supply of Urmia Lake's environmental flow requirements are presented in Table 5. The highest increase for reliability and resilience and highest decrease for vulnerability is again related to S4. According to Table 5, the implementation of water management scenarios has increased reliability and resilience and reduced vulnerability.

Table 5. Performance criteria of reliability, resilience and vulnerability for environment.

\begin{tabular}{|c|c|c|c|c|c|c|c|c|c|c|c|c|c|c|c|}
\hline \multirow{2}{*}{ Scenario } & \multicolumn{3}{|c|}{ So } & \multicolumn{3}{|c|}{ S1 } & \multicolumn{3}{|c|}{ S2 } & \multicolumn{3}{|c|}{ S3 } & \multicolumn{3}{|c|}{$\mathrm{S} 4$} \\
\hline & Rel & Res & Vul & Rel & Res & Vul & Rel & Res & Vul & Rel & Res & Vul & Rel & Res & Vul \\
\hline \multicolumn{16}{|l|}{$\mathrm{A} 2$} \\
\hline Zarrinehrud & 0.37 & 0.35 & 0.51 & 0.49 & 0.47 & 0.39 & 0.43 & 0.41 & 0.45 & 0.5 & 0.48 & 0.38 & 0.63 & 0.61 & 0.25 \\
\hline Siminehrud & 0.39 & 0.37 & 0.49 & 0.46 & 0.43 & 0.41 & 0.44 & 0.42 & 0.44 & 0.47 & 0.44 & 0.4 & 0.58 & 0.55 & 0.28 \\
\hline \multicolumn{16}{|l|}{ A1B } \\
\hline Zarrinehrud & 0.38 & 0.36 & 0.49 & 0.51 & 0.49 & 0.37 & 0.44 & 0.42 & 0.44 & 0.52 & 0.5 & 0.35 & 0.71 & 0.68 & 0.18 \\
\hline Siminehrud & 0.4 & 0.38 & 0.47 & 0.47 & 0.44 & 0.39 & 0.45 & 0.43 & 0.42 & 0.48 & 0.45 & 0.38 & 0.65 & 0.63 & 0.22 \\
\hline \multicolumn{16}{|l|}{ B1 } \\
\hline Zarrinehrud & 0.4 & 0.38 & 0.46 & 0.54 & 0.52 & 0.33 & 0.46 & 0.44 & 0.41 & 0.55 & 0.53 & 0.32 & 0.75 & 0.71 & 0.13 \\
\hline Siminehrud & 0.43 & 0.39 & 0.45 & 0.49 & 0.46 & 0.37 & 0.48 & 0.45 & 0.38 & 0.51 & 0.48 & 0.34 & 0.71 & 0.67 & 0.17 \\
\hline
\end{tabular}




\subsubsection{ASI, IWD and ESI}

For Zarrinehrud and Siminehrud River basins, there is a combination of three indicators (ASI, IWD and ESI) against five scenarios. Three combinations are obtained for the three emission scenarios of A2, $\mathrm{A} 1 \mathrm{~B}$ and B1, because these combinations change with climatic conditions. Table 6 presents sustainability indices of agriculture (according to Table 4) and irrigation water deficit for agriculture catchments.

Table 6. Evaluation of agricultural sustainability indices and irrigation water deficit for agriculture catchments.

\begin{tabular}{|c|c|c|c|c|c|c|c|c|c|c|}
\hline \multirow{2}{*}{ Scenario } & \multicolumn{5}{|c|}{$\mathrm{ASI}^{1}$} & \multicolumn{5}{|c|}{ IWD $^{2}$} \\
\hline & S0 & S1 & S2 & S3 & $\mathrm{S} 4$ & So & S1 & $\mathbf{S} 2$ & S3 & $\mathrm{S} 4$ \\
\hline \multicolumn{11}{|l|}{ A2 } \\
\hline Boukan 1 & 0.75 & 0.77 & 0.76 & 0.78 & 0.81 & 19.6 & 11.3 & 15.9 & 9.4 & 5.7 \\
\hline Boukan 2 & 0.76 & 0.78 & 0.77 & 0.79 & 0.82 & 9.7 & 5.6 & 8.2 & 5.3 & 3.2 \\
\hline Saghez & 0.64 & 0.72 & 0.67 & 0.74 & 0.78 & 35.2 & 15.8 & 30 & 13.9 & 7.6 \\
\hline Tekab & 0.44 & 0.6 & 0.53 & 0.62 & 0.7 & 98.2 & 65.9 & 82.7 & 45 & 15.4 \\
\hline Shahin Dezh & 0.58 & 0.66 & 0.62 & 0.68 & 0.77 & 119.6 & 80.3 & 100.7 & 54.8 & 18.7 \\
\hline ZRB & 0.77 & 0.8 & 0.78 & 0.82 & 0.84 & 33 & 19.4 & 25.3 & 12.9 & 6.9 \\
\hline ZLB & 0.76 & 0.79 & 0.77 & 0.81 & 0.83 & 34.2 & 20.6 & 26.4 & 14 & 7.2 \\
\hline \multicolumn{11}{|l|}{ A1B } \\
\hline Boukan 1 & 0.76 & 0.78 & 0.77 & 0.8 & 0.82 & 18.2 & 10.3 & 13.1 & 8.7 & 5.1 \\
\hline Boukan 2 & 0.77 & 0.79 & 0.78 & 0.81 & 0.83 & 9.2 & 5.2 & 7.2 & 4.6 & 2.8 \\
\hline Saghez & 0.65 & 0.73 & 0.68 & 0.75 & 0.79 & 33.9 & 14.6 & 28.5 & 13.2 & 6.7 \\
\hline Tekab & 0.45 & 0.61 & 0.54 & 0.63 & 0.71 & 95.6 & 63.2 & 79.3 & 42.9 & 13.9 \\
\hline Shahin Dezh & 0.59 & 0.67 & 0.63 & 0.69 & 0.78 & 116.2 & 76.8 & 96.4 & 52.2 & 16.9 \\
\hline ZRB & 0.78 & 0.81 & 0.8 & 0.83 & 0.85 & 31.9 & 17.5 & 22.5 & 10.7 & 5.2 \\
\hline ZLB & 0.77 & 0.8 & 0.79 & 0.82 & 0.84 & 32.1 & 18.2 & 23.5 & 11.8 & 5.7 \\
\hline \multicolumn{11}{|l|}{ B1 } \\
\hline Boukan 1 & 0.77 & 0.8 & 0.79 & 0.82 & 0.84 & 15.3 & 8.6 & 10.5 & 7 & 3.4 \\
\hline Boukan 2 & 0.78 & 0.81 & 0.8 & 0.83 & 0.85 & 8 & 3.9 & 5.8 & 3.6 & 1.8 \\
\hline Saghez & 0.67 & 0.75 & 0.7 & 0.77 & 0.81 & 31.7 & 12.8 & 24.1 & 11.1 & 4.6 \\
\hline Tekab & 0.47 & 0.63 & 0.56 & 0.65 & 0.73 & 89.1 & 56.4 & 71.5 & 38.1 & 10.8 \\
\hline Shahin Dezh & 0.61 & 0.69 & 0.65 & 0.71 & 0.8 & 108.9 & 68.9 & 87.4 & 46.6 & 13.2 \\
\hline ZRB & 0.8 & 0.83 & 0.82 & 0.84 & 0.87 & 26.1 & 12.1 & 16.6 & 8.4 & 1.7 \\
\hline ZLB & 0.79 & 0.82 & 0.81 & 0.83 & 0.86 & 27.7 & 13.6 & 18.1 & 9.7 & 2.8 \\
\hline
\end{tabular}

Notes: ${ }^{1}$ Agricultural Sustainability Index (ASI). ${ }^{2}$ Irrigation Water Deficit (IWD).

ASI varies between 0 and 1 . ASI values close to 1 indicate good performance. As shown in Table 6, in S0, ASI values for all agriculture catchments are less than 1 for A2, A1B, and B1 emission scenarios. This means that all agriculture catchments are under water stress and significant improvements for ASI can be achieved under different policies. The ASI value for all other considered scenarios has increased, but the highest amount of ASI for all agriculture catchments is related to B1S4, or the combination of crop pattern change with increasing total irrigation efficiency under B1 emission scenario. In addition, because the agriculture catchments of Saghez, Tekab and Shahin Dezh have higher potential to improve sustainability due to lower irrigation efficiency, in these areas, the increase in ASI is higher.

According to Table 6, water management strategies (S1-S4) lead to reduced water demand (by changing the crop pattern) and increased water supply (by increasing the irrigation efficiency), thereby mitigating the effects of climate change.

Irrigation water deficit (IWD) or unmet demand is a valuable index for evaluation. As shown in Table 6, in S0, IWD values for all agriculture catchments are significant. This deficit in many areas can reduce yield and reduce farmer's income. However, by the proposed solutions, IWD can be greatly improved. According to Table 6, the IWD value in B1S4 shows the highest improvement for all agriculture catchments. 
In Figure 9, the average amount of water is released from the Zarrinehrud and Siminehrud River basins to Urmia Lake in the future (2015-2040) under various emission scenarios is shown. The share of the environmental flow requirements (EFRs) of Lake Urmia from the Zarrinehrud and Siminehrud River basins is estimated as 1271 and 341 MCM per year, respectively. As shown in Figure 9, the maximum average amount of water entering the lake from these basins is related to the scenario of mixing the crop pattern change with the improvement of total irrigation efficiency under the B1 emission scenario (B1S4). Under this scenario, the average annual flow of water entering to Urmia Lake from the basins of Zarrinehrud and Siminehrud is 1292 and 351 MCM per year, and, as a result, the lake's environmental flow requirements will be supplied from these basins.
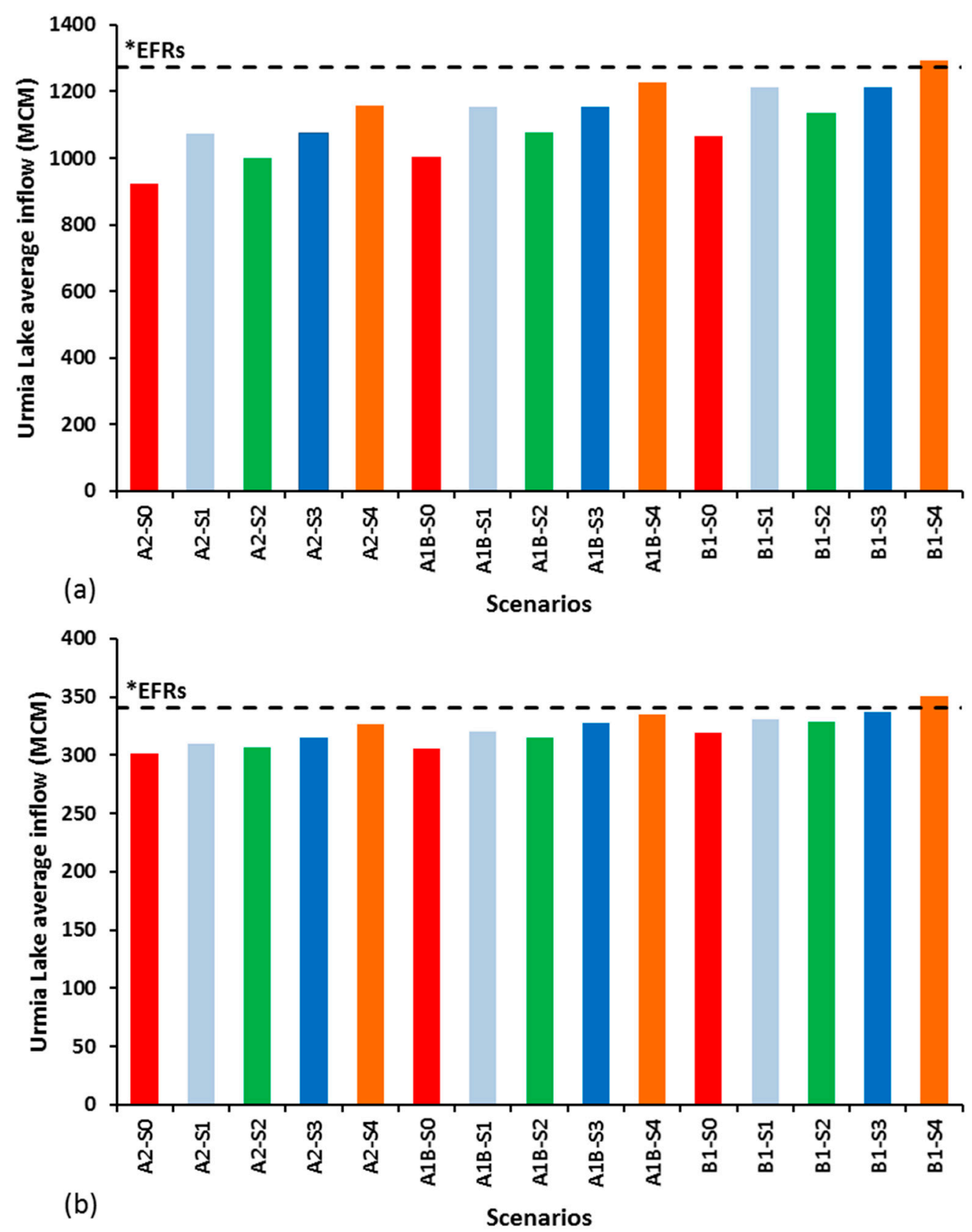

Figure 9. Average inflow to Urmia Lake under different scenarios (2015-2040): (a) from the Zarrinehrud River basin; and (b) from the Siminehrud River basin. EFRs: Environmental Flow Requirements. 
Table 7 shows the indices of environmental sustainability (according to Table 5), agricultural sustainability and irrigation water deficit (according to Table 6) for the Zerrinehrud and Siminehrud River basins. ASI is achieved based on weighted average of agriculture catchments (group sustainability) for each basin. The irrigation water deficit index is also based on the total deficit of agriculture catchments for each basin. According to Table 7, the highest ESI and ASI for both basins are related to B1S4. In addition, the greatest improvement in IWD is related to B1S4. In B1S4, both agriculture and the environment (Urmia Lake's environmental flow requirements) are stable.

Table 7. Evaluation of ESI ${ }^{1}$, ASI ${ }^{2}$ and IWD $^{3}$ for Zarrinehrud and Siminehrud River basins.

\begin{tabular}{|c|c|c|c|c|c|c|c|c|c|c|c|c|c|c|c|}
\hline \multirow{2}{*}{ Scenario } & \multicolumn{5}{|c|}{ ESI } & \multicolumn{5}{|c|}{ ASI } & \multicolumn{5}{|c|}{ IWD } \\
\hline & So & S1 & S2 & S3 & S4 & So & S1 & S2 & S3 & S4 & So & S1 & $\mathrm{S} 2$ & S3 & S4 \\
\hline \multicolumn{16}{|l|}{ A2 } \\
\hline $\begin{array}{l}\text { Zarrinehrud } \\
\text { Basin }\end{array}$ & 0.4 & 0.52 & 0.46 & 0.53 & 0.66 & 0.65 & 0.73 & 0.68 & 0.74 & 0.8 & 320.2 & 202 & 265.1 & 140.6 & 55.8 \\
\hline $\begin{array}{l}\text { Siminehrud } \\
\text { Basin }\end{array}$ & 0.42 & 0.49 & 0.47 & 0.5 & 0.61 & 0.75 & 0.77 & 0.76 & 0.78 & 0.81 & 29.3 & 16.9 & 24.1 & 14.7 & 8.9 \\
\hline \multicolumn{16}{|l|}{ A1B } \\
\hline $\begin{array}{l}\text { Zarrinehrud } \\
\text { Basin }\end{array}$ & 0.41 & 0.54 & 0.47 & 0.55 & 0.73 & 0.66 & 0.74 & 0.7 & 0.75 & 0.81 & 309.7 & 190.3 & 250.2 & 130.8 & 48.4 \\
\hline $\begin{array}{l}\text { Siminehrud } \\
\text { Basin }\end{array}$ & 0.43 & 0.5 & 0.48 & 0.51 & 0.68 & 0.76 & 0.78 & 0.77 & 0.8 & 0.82 & 27.4 & 15.5 & 20.3 & 13.3 & 7.9 \\
\hline \multicolumn{16}{|l|}{ B1 } \\
\hline $\begin{array}{l}\text { Zarrinehrud } \\
\text { Basin }\end{array}$ & 0.43 & 0.57 & 0.49 & 0.58 & 0.77 & 0.68 & 0.76 & 0.72 & 0.77 & 0.83 & 283.5 & 163.8 & 217.7 & 113.9 & 33.1 \\
\hline $\begin{array}{l}\text { Siminehrud } \\
\text { Basin }\end{array}$ & 0.45 & 0.52 & 0.51 & 0.54 & 0.73 & 0.77 & 0.8 & 0.79 & 0.82 & 0.84 & 23.3 & 12.5 & 16.3 & 10.6 & 5.2 \\
\hline
\end{tabular}

The aforementioned results show that, by adopting suitable management strategies, it is possible to improve agricultural sustainability and irrigation deficit, save water consumption, use saved water for environmental use (Urmia Lake) and improve its sustainability. The results of this research are in line with the results of other researchers $[1,3,15,21]$. The researchers concluded that improving irrigation efficiency would increase agricultural sustainability and save water consumption, and the saved water can be used for other intentions, including the environment.

\section{Conclusions}

In this research, environmental and agricultural sustainability indices are evaluated using performance criteria influenced by water management strategies and climate change. The irrigation water deficit index for agriculture catchments is also analyzed. The main results are summarized as follows:

1. The current unsustainable conditions in the Urmia Lake basin are due to climate change, water stress, poverty, agricultural development, cultivation of high-consumption crops, soil degradation, and low irrigation efficiency.

2. The climate scenarios of this study show an increase in the average temperature, precipitation, and actual evapotranspiration, and a decrease in streamflow for the future period (2015-2040) compared to the baseline period (1986-2010) for the Zarrinehrud and Siminehrud River basins.

3. In this study, the sustainability index (SI) was successfully used to assess water management strategies and climate change.

4. The results of this research showed that water management strategies including crop pattern change with increasing irrigation efficiency is necessary for achieving environmental and 
agricultural sustainability. By applying these strategies, the performance criteria of reliability and resilience are increased and the vulnerability decreases, thus the sustainability index increases.

5. The highest amount of environmental sustainability index (ESI) is related to the scenario of combining the crop pattern change with improving the total irrigation efficiency under the B1 emission scenario (B1S4). In this scenario, the average annual flow of water entering to Urmia Lake from the basins of Zarrinehrud and Siminehrud is 1292 and 351 MCM per year, respectively, and, as a result, the lake's environmental flow requirements (EFRs) will be supplied from these basins.

6. The highest amount of agricultural sustainability index (ASI) is related to the scenario of combining the crop pattern change with improving the total irrigation efficiency under the B1 emission scenario (B1S4). In this scenario, the average amount of irrigation water deficit (IWD) for Zarrinehrud and Siminehrud river basins were 33.1 and 5.2 MCM per year, respectively.

7. Water management strategies (S1-S4) lead to reduced water demand (by changing the crop pattern) and increased water supply (by increasing the irrigation efficiency), thereby mitigating the effects of climate change.

8. In the context of B1S4, the balance between agricultural sustainability (water challenge for food) and environmental sustainability (water challenge for the environment) will be achieved.

9. For more sustainability of Urmia Lake and reduction of its decline under other scenarios, other solutions can be considered, such as reducing the area of cultivated lands, conveying water between basins, cutting off the domestic water of Tabriz city and allocating it from another basin, and taking into account the consequences of the solutions.

10. The water management strategies discussed in this study are preliminary, as they did not consider the socio-economic consequences. Changing the crop pattern might reduce farmer's income, while increasing the irrigation efficiency using new technologies might increase the costs. It is therefore suggested that the economic aspects of the proposed water management strategies and the benefits of Urmia Lake restoration be investigated in subsequent studies.

Acknowledgments: The authors express their gratitude to researchers from the Stockholm Environment Institute (SEI), in particular Jack Sieber, Stephanie Galaitsi, Brian Joyce, and Devaraj de Condappa, for their valuable guidance. The authors also thank the editor and two anonymous reviewers for their constructive and valuable comments that have significantly improved this manuscript.

Author Contributions: This manuscript is a result of the Doctoral research of Jamal Ahmadaali under the supervision of Gholam-Abbas Barani and the advising of Kourosh Qaderi and Behzad Hessari. All authors designed the study, developed the methodology, discussed the results and wrote the paper.

Conflicts of Interest: The authors declare no conflict of interest.

\section{References}

1. Cai, X.; McKinney, D.C.; Rosegrant, M.W. Sustainability Analysis for Irrigation Water Management: Concepts, Methodology and Application to the Aral Sea Region; Environment and Production Technology Division, International Food Policy Research Institute: Washington, DC, USA, 2001.

2. Shadkam, S. Preserving Urmia Lake in a Changing World. Ph.D. Thesis, Wageningen University, Wageningen, The Netherlands, 2017.

3. Törnqvist, R.; Jarsjö, J. Water Savings through Improved Irrigation Techniques: Basin-Scale Quantification in Semi-Arid Environments. Water Resour. Manag. 2012, 26, 949-962. [CrossRef]

4. Haghighi, A.T.; Kløve, B. Design of Environmental Flow Regimes to Maintain Lakes and Wetlands in Regions with High Seasonal Irrigation Demand. Ecol. Eng. 2017, 100, 120-129. [CrossRef]

5. Shadkam, S.; Ludwig, F.; van Vliet, M.T.; Pastor, A.; Kabat, P. Preserving the World Second Largest Hypersaline Lake under Future Irrigation and Climate Change. Sci. Total Environ. 2016, 559, 317-325. [CrossRef] [PubMed]

6. Jalili, S.; Hamidi, S.A.; Namdar Ghanbari, R. Climate Variability and Anthropogenic Effects on Lake Urmia Water Level Fluctuations, Northwestern Iran. Hydrol. Sci. J. 2016, 61, 1759-1769. [CrossRef] 
7. AghaKouchak, A.; Norouzi, H.; Madani, K.; Mirchi, A.; Azarderakhsh, M.; Nazemi, A.; Nasrollahi, N.; Farahmand, A.; Mehran, A.; Hasanzadeh, E. Aral Sea Syndrome Desiccates Lake Urmia: Call For Action. J. Great Lakes Res. 2015, 41, 307-311. [CrossRef]

8. Khatami Mashhadi, S. Nonlinear Chaotic and Trend Analyses of Water Level at Urmia Lake, Iran. Master's Thesis, Lund University, Lund, Sweden, 2013.

9. Hamzekhani, F.G.; Saghafian, B.; Araghinejad, S. Environmental Management in Urmia Lake: Thresholds Approach. Int. J. Water Resour. Dev. 2016, 32, 77-88. [CrossRef]

10. Hassanzadeh, E.; Zarghami, M.; Hassanzadeh, Y. Determining the Main Factors in Declining the Urmia Lake Level by Using System Dynamics Modeling. Water Resour. Manag. 2012, 26, 129-145. [CrossRef]

11. Shadkam, S.; Ludwig, F.; van Oel, P.; Kirmit, Ç.; Kabat, P. Impacts of Climate Change and Water Resources Development on the Declining Inflow into Iran's Urmia Lake. J. Great Lakes Res. 2016, 42, 942-952. [CrossRef]

12. Sietz, D.; Lüdeke, M.K.; Walther, C. Categorisation of typical vulnerability patterns in global drylands. Glob. Environ. Chang. 2011, 21, 431-440. [CrossRef]

13. Yates, D.; Purkey, D.; Sieber, J.; Huber-Lee, A.; Galbraith, H.; West, J.; Herrod-Julius, S.; Young, C.; Joyce, B.; Rayej, M. Climate Driven Water Resources Model of the Sacramento Basin, California. J. Water Resour. Plan. Manag. 2009, 135, 303-313. [CrossRef]

14. Joyce, B.A.; Mehta, V.K.; Purkey, D.R.; Dale, L.L.; Hanemann, M. Modifying Agricultural Water Management to Adapt to Climate Change in California's Central Valley. Clim. Chang. 2011, 109, 299-316. [CrossRef]

15. Mehta, V.K.; Haden, V.R.; Joyce, B.A.; Purkey, D.R.; Jackson, L.E. Irrigation Demand and Supply, Given Projections of Climate and Land-use Change, in Yolo County, California. Agric. Water Manag. 2013, 117, 70-82. [CrossRef]

16. Blanco-Gutiérrez, I. Economic-Hydrologic Analysis of Water Management Strategies for Balancing Water for Nature and Water for Food: Implications for the Guadiana River Basin. Ph.D. Thesis, Polytechnical University of Madrid, Madrid, Spain, 2010.

17. Hunter, C.; Gironás, J.; Bolster, D.; Karavitis, C.A. A Dynamic, Multivariate Sustainability Measure for Robust Analysis of Water Management under Climate and Demand Uncertainty in an Arid Environment. Water 2015, 7, 5928-5958. [CrossRef]

18. Safavi, H.R.; Golmohammadi, M.H. Evaluating the Water Resource Systems Performance Using Fuzzy Reliability, Resilience and Vulnerability. Iran-Water Resour. Res. 2016, 12, 68-83.

19. Asefa, T.; Clayton, J.; Adams, A.; Anderson, D. Performance Evaluation of a Water Resources System Under Varying Climatic Conditions: Reliability, Resilience, Vulnerability and Beyond. J. Hydrol. 2014, 508, $53-65$. [CrossRef]

20. Safavi, H.R.; Golmohammadi, M.H.; Sandoval-Solis, S. Scenario Analysis for Integrated Water Resources Planning and Management under Uncertainty in the Zayandehrud River Basin. J. Hydrol. 2016, 539, 625-639. [CrossRef]

21. Yilmaz, B.; Harmancioglu, N.B. An Indicator Based Assessment for Water Resources Management in Gediz River Basin, Turkey. Water Resour. Manag. 2010, 24, 4359-4379. [CrossRef]

22. Yates, D.; Sieber, J.; Purkey, D.; Huber-Lee, A. WEAP21: A Demand-, Priority-, and Preference-Driven Water Planning Model: Part 1: Model Characteristics. Water Int. 2005, 30, 487-500. [CrossRef]

23. Yates, D.; Purkey, D.; Sieber, J.; Huber-Lee, A.; Galbraith, H. WEAP21: A Demand-, Priority-, and Preference-Driven Water Planning Model: Part 2: Aiding Freshwater Ecosystem Service Evaluation. Water Int. 2005, 30, 501-512. [CrossRef]

24. Yekom Consulting Engineers. Water Consumption Reduction of Agricultural Sector in Simineh Roud and Zarrineh Roud Watershed Basin; Urmia Lake Restoration National Committee, Ministry of Energy: Lake Urmia, Iran, 2016.

25. Urmia Lake Restoration National Committee. Necessity of Lake Urmia Resuscitation, Causes of Drought and Threats; Report No: ULRP-6-4-3-Rep 1; Urmia Lake Restoration National Committee: Tehran, Iran, 2015.

26. Esteve, P.; Varela-Ortega, C.; Blanco-Gutiérrez, I.; Downing, T.E. A Hydro-Economic Model for the Assessment of Climate Change Impacts and Adaptation in Irrigated Agriculture. Ecol. Econ. 2015, 120, 49-58. [CrossRef]

27. Ahmadaali, J.; Barani, G.A.; Qaderi, K.; Hessari, B. Calibration and Validation of Model WEAP21 for Zarrinehrud and Siminehrud Basins. Iran. J. Soil Water Res. 2017, 48, 823-839. (In Persian) 
28. Stockholm Environment Institute, U.S. Center (SEI-US). WEAP User Guide; Stockholm Environment Institute, U.S. Center: Somerville, MA, USA, 2015.

29. Ingol-Blanco, E.; McKinney, D.C. Development of a Hydrological Model for the Rio Conchos Basin. J. Hydrol. Eng. 2013, 18, 340-351. [CrossRef]

30. Blanco-Gutiérrez, I.; Varela-Ortega, C.; Purkey, D.R. Integrated Assessment of Policy Interventions for Promoting Sustainable Irrigation in Semi-Arid Environments: A Hydro-Economic Modeling Approach. J. Environ. Manag. 2013, 128, 144-160. [CrossRef] [PubMed]

31. Moriasi, D.N.; Arnold, J.G.; Van Liew, M.W.; Bingner, R.L.; Harmel, R.D.; Veith, T.L. Model Evaluation Guidelines for Systematic Quantification of Accuracy in Watershed Simulations. Trans. ASABE 2007, 50, 885-900. [CrossRef]

32. Legates, D.R.; McCabe, G.J. Evaluating the Use of "Goodness-of-Fit" Measures in Hydrologic and Hydroclimatic Model Validation. Water Resour. Res. 1999, 35, 233-241. [CrossRef]

33. Intergovernmental Panel on Climate Change. IPCC Fourth Assessment Report. Climate Change: Synthesis Report; Intergovernmental Panel on Climate Change: Geneva, Switzerland, 2007.

34. Mach, K.; Mastrandrea, M. Climate Change 2014: Impacts, Adaptation, and Vulnerability; Field, C.B., Barros, V.R., Eds.; Cambridge University Press: Cambridge, MA, USA, 2014; Volume 1.

35. Semenov, M.A.; Stratonovitch, P. Use of Multi-Model Ensembles from Global Climate Models for Assessment of Climate Change Impacts. Clim. Res. 2010, 41, 1-14. [CrossRef]

36. Guo, T.; Mehan, S.; Gitau, M.W.; Wang, Q.; Kuczek, T.; Flanagan, D.C. Impact of Number of Realizations on the Suitability of Simulated Weather Data for Hydrologic and Environmental Applications. Stoch. Environ. Res. Risk Assess. 2017, 1-17. [CrossRef]

37. Santikayasa, I.P.; Babel, M.S.; Shrestha, S. Assessment of the Impact of Climate Change on Water Availability in the Citarum River Basin, Indonesia: The use of Statistical Downscaling and Water Planning Tools. In Managing Water Resources under Climate Uncertainty; Springer: Basel, Switzerland, 2015; pp. 45-64.

38. Iran Ministry of Agriculture Jihad. Report of Current Agricultural Status in Urmia Lake Basin; Iran Ministry of Agriculture Jihad: Tehran, Iran, 2014.

39. Iran Ministry of Energy. Report of Current Irrigation Status in Urmia Lake Basin; Iran Ministry of Energy: Tehran, Iran, 2014.

40. Iran Ministry of Energy, Deputy of Water and WasteWater, Macro Planning Bureau. The Comprehensive Water Management in the Aras, Sefidrood, between Sefidrood and Haraz, Atrac and Urmia Basins_Agricultural Water Use Study in Urmia Lake Basin; Report Number: 2385070-4420-19464; Iran Ministry of Energy: Tehran, Iran, 2013.

41. Loucks, D.P. Quantifying Trends in System Sustainability. Hydrol. Sci. J. 1997, 42, 513-530. [CrossRef]

42. Loucks, D.P.; Van Beek, E.; Stedinger, J.R.; Dijkman, J.P.; Villars, M.T. Water Resources Systems Planning and Management: An Introduction to Methods, Models and Applications; United Nations Educational, Scientific and Cultural Organization: Paris, France, 2005.

43. Srdjevic, Z.; Srdjevic, B. An Extension of the Sustainability Index Definition in Water Resources Planning and Management. Water Resour. Manag. 2017, 31, 1695-1712. [CrossRef]

44. Santikayasa, I.P.; Babel, M.S.; Shrestha, S.; Jourdain, D.; Clemente, R.S. Evaluation of Water Use Sustainability under Future Climate and Irrigation Management Scenarios in Citarum River Basin, Indonesia. Int. J. Sustain. Dev. World Ecol. 2014, 21, 181-194. [CrossRef]

45. Sandoval-Solis, S.; McKinney, D.C.; Loucks, D.P. Sustainability Index for Water Resources Planning and Management. J. Water Resour. Plan. Manag. 2011, 137, 381-390. [CrossRef]

46. Abbaspour, M.; Nazaridoust, A. Determination of Environmental Water Requirements of Lake Urmia, Iran: An Ecological Approach. Int. J. Environ. Stud. 2007, 64, 161-169. [CrossRef]

(C) 2018 by the authors. Licensee MDPI, Basel, Switzerland. This article is an open access article distributed under the terms and conditions of the Creative Commons Attribution (CC BY) license (http:/ / creativecommons.org/licenses/by/4.0/). 